As a result of this decision, fin whales will be completely protected in both the Southern Hemisphere and the North Pacific, and the only stock that can legally be fished is the small one in the North Atlantic. The details are in the table.

Fin whale

Sei whale

Bryde's whale

Minke whale

Sperm whale

Male

Female
Quotas and Catches 1975/6 and 1976/7

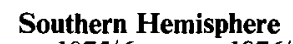

$\begin{array}{cc}1975 / 6 & 1976 / 7 \\ \text { quota catch } & \text { quota }\end{array}$

$220 \quad 206$

$2230 \quad 1820$

nil

nil

6810

6034

5870

4870 nil

1863

nil
8900

3894

897

\section{North Pacific}

$1975 / 6$
quota catch

nil nil

nil

1363

nil

ail
1976/7

quota

nil

nil

1000

5200

3100
North Atlantic

$1975 / 6 \quad 1976 / 7$

quota quota

$363 \quad 344$

$2550 \quad 2483$

All those nils, coupled with the continued downward spiral of both quotas and catches, are the highest possible condemnation of the bad management of the International Whaling Commission. Had the commission listened to its scientists twenty years ago, there could have been a flourishing whaling industry today, instead of a dying one.

Next year's meeting is at Canberra, Australia.

\title{
Marine Mammals and Man
}

The current generation gap in conservation seems to lie between 'old-timers' who concentrate on species studies and the up and coming scientists who are increasingly conscious of the interdependence of all living things and prefer to study ecosystems. This was conspicuous at the meeting at Bergen, Norway, in September 1976, when some 200 marine mammal ecologists, biostatisticians and other specialists assembled from all five continents for a Scientific Consultation on Marine Mammals, sponsored by FAO. The aim of this meeting was to get as complete a picture as possible of the status of the world's whales, dolphins, seals, marine otters, dugongs and manatees, their importance as a resource and how their stocks can be conserved. The final result will not be known until the publication of the report, early in 1977, of the working party which after the conference retired to an island retreat to digest the reports of the meeting's 23 working groups, under the guidance of Dr Sidney Holt, director of the FAO/UNEP Marine Mammals Project in Malta, whose brain-child the whole exercise was.

Almost every species of marine mammal is to some degree threatened by man's activities, whether by direct commercial exploitation, as for whales and seals, or by killing because they directly compete with man for seafood, as with seals and otters, or even purely incidentally by being caught in fish nets, as with dolphins. DDT and dieldrin concentrations in dolphin blubber, combined with the effects of such chemicals in the marine environment as a whole, point up the pollution threat, and the general availability of firearms and motor-boats has given a new meaning to subsistence hunting by Inuit (Eskimo) and other peoples dependent on wild food resources. Loss of habitat, except 
by the pollution of estuaries, affects marine mammals far less than terrestrial ones, although breeding beaches are increasingly being disturbed and migrations may be affected by shipping movements. Indeed the only marine mammal that seems to exist entirely undisturbed by man, apart from some of the rarer species of whale, is the Antarctic crab-eater seal, presumably because of the remoteness of its rookeries. However, the removal of the great bulk of the Antarctic whale stocks and the harvesting of krill, which has already begun, are causing changes in the ecosystem that are bound to affect the crab-eater.

\section{Oryx 100\% Fund}

The following are the latest grants from the FPS Oryx $100 \%$ Fund:

$£ 500$ to J. Lovisek for studies to facilitate management and conservation of endangered caimans in Bolivia and Brazil;

$£ 300$ to Dr J. Juvik for studies of Geochelone tortoises in Madagascar;

$\mathbf{1 3 0 0}$ for Durham University expedition to St Vincent for continuation of studies on the St Vincent parrot, reported in Oryx, July 1976, page 324;

£270 to John Newby for meteorological equipment needed for migration studies of the endangered scimitar-horned oryx and addax in Tchad, which could greatly help in controlling poaching of these antelopes;

$£ 250$ to G. Stutzin for equipment for the game guards protecting the Andean huemul;

$£ 100$ for Aberdeen University expedition to Aride (Seychelles) to study endangered birds;

$£ 92$ to Wahab Owadally, Conservator of Forests in Mauritius, for the distribution of books on wildlife to Mauritius schools.

\section{Legacies and Gifts}

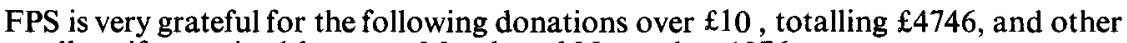
smaller gifts received between March and November 1976:

\section{Legacies}

Miss H.K. Jillard, additional to $£ 25,000$ already reported

Dr. J.L. Linzell

Gifts

S. Marchant

Mrs Diana Spearman

New Moorgate Trust Fund

Mrs M.A.E. Balston and Mrs J.A. Southby

$£ 1000$

Dr E.T.O. Slater

$£ 13$

Oryx $100 \%$ Fund

K. Richards

Tom Cretain

Philip English

Thomas Forman \& Sons Ltd

Dr Ruth Gipps

\& Sons Ltd

$£ 30$

$£ 25$

$£ 10$

$£ 30$

$£ 30$
Mrs Tyrwhitt

R.G. Chapple

W.D. Francis

Mrs A.M. Jackson

K.J. Proud 